\title{
Comment
}

\section{Our Forgotten Constitution: A Bicentennial Comment}

\begin{abstract}
Akhil Reed Amar†
This is a story about the Constitution that begins with some rather shocking facts: The parchment that all of us-practitioners, judges, scholars-have been using for the last century as the definitive copy of the supreme law of the land, is not. The handwritten, handsigned document enshrined in the National Archives and reprinted everywhere was never ratified by "We the People of the United States." Even the Senate is on record as acknowledging that this revered document has virtually no legal significance. ${ }^{1}$ No kidding.

Fortunately, the document that was ratified by Americans in the late 1780 's -an edition printed in New York several days after the signing of the parchment in Philadelphia-bears a close resemblance to the text we have all grown up with. Although the official printed archetype of the Constitution (whose existence has for many years been a well kept if unintended secret) is marked by different punctuation and capitalization, the words are the same as those in the familiar parchment. ${ }^{2}$ Thus, the National Archives version is probably good enough for government work. ${ }^{3}$

If, then, little of immediate legal consequence turns on the existence of the real Constitution, why do I raise the issue? First, because the story of how Americans have come to forget the official text of the Constitution
\end{abstract}

\footnotetext{
† Assistant Professor, Yale Law School. This story was composed for a Bicentennial baby, Drew Wright, YLS 2012, in the hope that it might prove useful as he and his generation lead our nation towards its Tricentennial. Special thanks to James Hutson, Cathy Iino, and Ron Wright for their helpful comments on earlier drafts.

1. See S. Doc. No. 49, 87th Cong., Ist Sess. 49-94 (1961) (historical notes authored by Denys P. Myers). Section I of this essay owes a great debt to the archival labors of Mr. Myers. See also Rapport, Printing the Constitution: The Convention and Newspaper Imprints, August-November 1787, Prologue, Fall 1970, at 69 (discussing early printed editions of Constitution).

2. With de minimis exceptions, see infra text accompanying note 43 .

3. See infra note 25 .
} 
We ratified makes for an interesting tale in itself, and one that should be told in this Bicentennial year. Second, because that tale has some important lessons for us about law, history, and the way that storytelling colors both of them.

\section{A Tale of Two Constitutions}

On September 15, 1787, the delegates to the Philadelphia Convention finally reached agreement on a complete set of words. After nearly four months of deliberations carefully veiled from outside scrutiny, the Convention was ready to go public with its product. But precisely how, logistically, to do this? In a world without floppy disks, word processors, photocopiers, facsimile printers, or even mimeograph machines, 18 th century Americans generally relied on two technologies to generate hard copies of legal texts: engrossing (handwriting) and printing. The men at Philadelphia availed themselves of both on September 15. Although James Madison's notes are uncharacteristically silent on this point, his fellow delegate James McHenry of Maryland recorded the following entry in his daily journal:

15 Sepr.

The question being taken on the [Constitution] agreed to unanimously-

Ordered [Constitution] to be engrossed and 500 copies struck [printed]-Adjourned till monday the 17th. ${ }^{*}$

Convention President George Washington's September 15 diary entry confirms McHenry's:

[A]djourned 'till Monday that the Constitution which it was proposed to offer to the People might be engrossed-and a number of printed copies struck off.

Both engrossing and printing were carried out under the direction of the Convention's Committee of Style, which on September 17 presented the assembly with a single four page engrossed copy for endorsement.6 After the text was read aloud, and a last-minute amendment agreed to and penned in, 39 of the 42 delegates present registered their assent to the plan by signing the parchment. ${ }^{7}$ The Convention then charged Secretary

4. 2 The Records of the Federal. Convention of 1787, at 633-34 (M. Farrand rev. ed.

1937) [hereinafter FARRAND RECORDS].

5. 3 id. at 81 .

6. S. Doc. No. 49 , supra note 1 , at 51 .

7. M. FarRand, The Framing of The Constitution of The United States 193-94 (1913). 
William Jackson to deliver the document to the Congress organized under the existing Articles of Confederation, sitting in New York City. ${ }^{8}$

Although it is possible that each Convention delegate carefully examined the parchment before endorsing it, such a tedious practice would have painfully slowed the signing ceremony, since no more than two or three delegates could have examined the document simultaneously. More likely, each delegate simply referred to his own printed copy of a draft Constitution that the Committee of Style had distributed on September 12, and that had served thereafter as the Convention's working paper. Many delegates may well have assumed the parchment to be identical to the September $12 \mathrm{draft}$, as amended - an assumption apparently confirmed by the oral reading of the engrossed document. In fact, this assumption was false: The two versions differed in small ways-e.g., punctuation-unlikely to be detected by any delegate listening to the reading of the engrossed copy while carefully following along by reading his own copy of the September 12 print.

On September 18, the 500 official printed copies that had been authorized three days earlier were struck and distributed to the remaining delegates. As with the September 12 draft print, however, the September 18 print punctuated the constitutional text quite differently from the engrossed parchment signed on September $17 .^{\circ}$ Indeed, the punctuation of the September 18 print diverged considerably from its September 12 precursor as well. For example, the earlier print used periods after each enumeration of legislative power in Article I, section 8, whereas the September 18 document used colons. (The parchment used semi-colons, and thus differed from both prints.)

On September 20, William Jackson reached New York and laid before Congress the engrossed Convention report. Apparently, the parchment was once again read aloud, but here too, each delegate probably relied on his own printed copy. ${ }^{10}$ In any event, when Congress voted unanimously on September 28 to send the proposed Constitution to the People of each state for ratification, Secretary of Congress Charles Thompson reprinted 100 copies of the September 18 print for transmission to the states. ${ }^{11}$

No one in the several states had access to the signed parchment buried in the files of Congress in New York. Rather, the September 28 reprint of the September 18 print was itself reprinted-with great fidelity-in lots of up to 10,000 for mass distribution to the polity. ${ }^{12}$ This was the version submitted to the People of the United States as they chose their delegates

8. 2 FARRAND Records, supra note 4, at 650 (notes of James McHenry).

9. Cf. infra text accompanying note 25 .

10. S. Doc. No. 49 , supra note 1 , at $49,52,55$. These printed copies were based on the September 18 print, which had been reprinted in New York City on September 22 by a local publisher, John McLean, in his Independent Journal or, The General Advertiser. Id. at 54-56, 69.

11. S. Doc. No. 49 , supra note 1 , at $56-57,69-70$.

12. Id. at 57,70 . 
to various ratifying conventions. This was the version that those ratifying conventions in turn used. And this was the version that 9 out of 13 ratifying conventions expressly included in their formal instruments of ratification submitted to Secretary Thompson. ${ }^{\text {is }}$

By 1789 , eleven state conventions had ratified the new Constitution-enough for it to go into effect under Article VII. One of the first acts of the new Congress was to authorize the printing of "a correct copy of the Constitution of the United States."14 This copy, published in 1789 by Francis Childes and John Swaine, "printers to the United States," followed, with minor printing deviations, the printed archetype of September 28, 1787-not the engrossed parchment. ${ }^{15}$

Unfortunately, in the confused administrative transition from government under the Articles to government under the Constitution, no one master copy of the September 28 print was preserved as such. ${ }^{16}$ Nevertheless, according to a 1961 Senate document authored by Denys P. Myers, a former State Department officer who carefully examined historical records after the Department received an inquiry from a foreign government for an "official" copy of the Constitution of the United States:

The failure to designate some copy as the archetype to be regarded as the final text of reference created no question for many years. . . . The text printed in the session laws of 1789 , which was undoubtedly reproduced from a copy of the print of September 28, 1787, was accepted as the real thing. . . . For approximately a century this printed archetype was the model followed in official editions of the laws and the other governmental issues. Discrepancies in editing crept in-the texts printed with the laws in the official editions of 1796, 1815 and 1845 are not identical. On the other hand, the frequent prints for the use of the Houses of Congress in what became the Senate and House Manuals reproduced the printed archetype with great fidelity . . . ${ }^{17}$

Meanwhile, what became of the Philadelphia parchment-which, after all, had also been authorized by the Convention delegates during the momentous days of September, 1787? For many years, the document was apparently lost or forgotten, buried in the disorganized files of the old

13. "In an instrument of ratification it is customary to repeat word for word the document which is ratified." Id. at 70-71. The four states departing from this custom were Connecticut, Delaware, Massachusetts and New Hampshire. Id. All thirteen ratification instruments, including the nine reprints of the September 28 text, may be found in 2 DEPARTMENT OF STATE, BuREaU of Rolls and Library, Documentary History of the Constitution of the United States, 1787-1870, at 24-203 (1894).

14. See Acts Passed at a Congress of the United States of America, Begun and Held at the City of New-York, on Wednesday the Fourth of March in the Year M, DCC, LXXXIX iii (1789) (Childes \& Swaine, publishers, New York) (emphasis added).

15. Id. at i.

16. S. Doc. No. 49 , supra note 1 , at $67-94$.

17. Id. at $89,60,49$. 
Confederation. In 1818, Congress directed that the theretofore secret official journal of the Philadelphia Convention be published. Secretary of State John Quincy Adams supervised the compilation of the primary documents, and the product of his labors was published in $1819 .{ }^{18}$ Although this publication failed to include the text of the engrossed parchment, the work of organizing loose files apparently brought to light its original four pages. ${ }^{19}$ The following year, the State Department published an edition of the engrossed text as an item of historical interest. ${ }^{20}$

Two factors account for the parchment's later ascendancy. First, repeated reprinting of the September 28 print resulted in increasing numbers of discrepancies due to compounded printers' errors; yet, as noted above, no single copy of the print had been preserved as an official touchstone. As a result, "[w]hen accumulated variations were sought to be corrected by collation with an original, the engrossed copy . . . was the only known archetype."21 Second, in 1876 the State Department put the handsigned engrossed parchment on public display side by side with the handsigned engrossed parchment of the Declaration of Independence. The centennial magic of the Declaration at the 1876 Philadelphia exposition rubbed off on its constitutional counterpart. In effect, the parchment Constitution was gilt by association, and became in popular folklore the Constitution, the icon of a nation desperately in need of unifying symbols in the wake of the Civil War. This time, it was the September 28 print that was forgotten in the excitement. The transition from print to parchment was as quick and dramatic as it was unconscious and uninformed: Only two years later, in 1878, the parchment was first reproduced under the direction of Congress as the apparent official text of the Constitution. ${ }^{22}$ Since then, "the engrossed copy of the Constitution has been the commonly accepted archetype. It has been regularly reproduced from that period in both the House and Senate Manuals and in the United States Code."2s While the four page parchment has been on public display for over 100 years, ${ }^{24}$ the printed archetype has faded into the mists of history.

18. 1 FARRAND Records, supra note 4 , at xii.

19. S. Doc. No. 49 , supra note 1 , at 53 \& n.17.

20. Id. at 89.

21. Id. at 61 .

22. Id. at 49, 54, 91-92. See Revised Statutes of the United States (2d ed. 1878).

23. S. Doc. No. 49 , supra note 1 , at 54.

24. From the mid 1880's until 1921, the parchment was on display at the Department of State. From 1924 to 1952, the document was exhibited at the Library of Congress, and was thereafter transferred to the National Archives. 


\section{Morals of the Tale}

\section{A. First Principles}

What are we to make of all this? First of all, we must of course decide which set of ink spots is, from a legal point of view, the official copy of the Constitution. To be sure, given the de minimis nature of the differences between print and parchment, few, if any, important legal issues should turn on our choice of text. ${ }^{28}$ It is, after all, "a constitution we are expounding." ${ }^{\text {"26 }}$ Yet precisely because of this-precisely because we are dealing with one of the most important legal texts in human history-a certain degree of fastidiousness seems appropriate.

Fastidiousness also yields educational advantages, for our choice of texts requires us to dust off and put to work first principles. And with these principles in mind, the choice of the September 28 print over the September 17 parchment is easy. The point here is not that individual delegates in Convention and Congress were more likely to have relied on precursors of the print than on the parchment itself. Rather, it is that if we seek to find our true higher law, we must look beyond Philadelphia and New York. The Constitution is our supreme law, superior to ordinary legislation, simply because its source was the supreme lawmaker, superior to ordinary legislatures: "We the People of the United States." Once we remember that it was popular ratification that transformed a mere proposal into binding law, ${ }^{27}$ we cannot but choose as our supreme legal text the edition that was in fact offered to and endorsed by the People of the United States ipsissimis verbis; namely, the September 28 print.

Both Federalists and Anti-Federalists in the late 1780's shared a pas-

25. Of course, I am not suggesting that seemingly small points of punctuation are never relevant to our interpretation of constitutional text. See Amar, A Neo-Federalist View of Article III: Separating the Two Tiers of Federal Jurisdiction, 65 B.U.L. REv. 205, 217 n.50 (1985) (relying on punctuation of exceptions and regulations clause); Gunther, Congressional Power to Curtail Jurisdiction: An Opinionated Guide to the Ongoing Debate, 36 Stan. L. REv. 895, 901 (1984) (same). The punctuation differences between print and parchment, however, largely involve details of capitalization, abbreviation, and the choice between colons and semi-colons-differences which I, at least, believe unlikely to lead to significant differences in interpretation.

Professor Farrand offers a fascinating account of a clause in which an apparently small change in punctuation was attempted in order to effect a large change in meaning. According to Farrand, Gouverneur Morris, as chief draftsman of Philadelphia Committec of Style, unsuccessfully attempted to substitute a semi-colon for a comma separating the purposive "to pay the debts and provide for the common defence and general welfare" clause from the rest of the taxing clause of art. $1, \S 8$, para. 1 . As punctuated by Morris, the clause might have implied an independent power in Congress to pursue the general welfare, thus circumventing the gaps created by the other enumerations of Article I. See M. FARRAND, supra note 7, at 182-83; see also 3 FARRAND ReCORdS, supra note 4, at 379 (remarks of Albert Gallatin in House of Representatives supporting Farrand's account of Morris' machinations); id. at 456-58 (excerpts from Memoirs of John Quincy Adams) (firsthand account of renewed debate about national power and punctuation of general welfare clause, sparked by Adams' 1819 printing of Convention records, including Committee of Style draft of September 12).

26. McCulloch v. Maryland, 17 U.S. (4 Wheat.) 316, 407 (1819) (emphasis in original).

27. See, e.g., McCulloch, 17 U.S. at 403; The Federalist No. 22, at 152 (A. Hamilton) (C. Rossiter ed. 1961); id. No. 40, at 253 (J. Madison); 1 FARRAND ReCoRds, supra note 4, at 253 (remarks of James Wilson). 
sionate devotion to the idea of popular sovereignty, and understood its legal implications. ${ }^{28}$ It is thus not surprising that when the first Congress in 1789 ordered the printing of a "correct" copy of the Constitution (an adjective, parenthetically, that has never again appeared in any congressional directive concerning constitutional publication), ${ }^{29}$ nobody doubted the correctness of the September 28 print. Nor is it surprising that this print, as reprinted by Childes and Swaine, stood as the official text for almost a century.

What does seem surprising is that Americans in 1876 apparently forgot their true Constitution even as they set out to publicly celebrate their history. And yet perhaps we should not be so surprised. In this, our own year of commemoration, we may well be committing some of the same mistakes. Even more sobering, our mistakes today may not be limited to our popular celebrations, but may well infect our case law and our scholarship-and their effects may not be de minimis.

\section{B. Of Law and History}

\section{Half-hearted History}

One partial explanation for the mid-nineteenth century shift from print to parchment is sheer sloppiness of historical research: Americans came to accept the parchment as their official Constitution because they had forgotten that any other version existed, and legal historians neglected to remind them. ${ }^{30}$ To put the point more softly, the accessibility of historical materials tends to skew the enterprise of legal history. When print was accessible and parchment not, lawyers used print; when the relative accessibility of the documents changed, so did lawyers' habits.

Something similar happens today. In interpreting the Constitution, judges, litigators, and even law professors tend to rely most on those primary sources that are most accessible-namely, The Federalist Papers and Max Farrand's The Records of the Federal Convention of 1787. Both are still in print, easy to read, relatively short, carefully indexed, easily found in libraries and book stores, and available in inexpensive (and thus easy-to-own) paperback editions. Other primary sources (such as pamphlets written during the ratification era by men other than Hamilton, Madison and Jay ${ }^{31}$ and records of various state ratifying conven-

28. See generally Amar, Of Sovereignty and Federalism, 96 YALE L.J. 1425, 1429-66 (1987).

29. S. Doc. No. 49 , supra note 1 , at 92.

30. Even if one believes, as I do, that the Constitution may be amended by certain forms of popular referenda that transcend the formal requirements of Article $\mathrm{V}$, see infra text accompanying note 50, it would be difficult to argue that popular acceptance of the parchment in and after 1876 constitutes such a de facto amendment. Not only was no vote ever taken on anything, but the People of America have never even been made aware of the existence of competing texts from which to choose. In any event, the issue is largely mooted by the de minimis character of the differences between the two texts.

31. See, e.g., Pamphlets on the Constitution of the United States (P. Ford ed. 1888 \& 
tions $^{32}$ ) receive far less attention-at least in part, I believe, because these documents are less accessible to lawyers.

Once again, first principles suggest that we reconsider our choice of texts. Just as the parchment signed by the Convention is inferior to the September 28 print because the latter is the People's Constitution, so primary sources from the Convention should be inferior to primary sources from the ratification period because the latter comprise the People's legislative history of the People's law. The People in 1787-88 had no access to the then-secret records of the Philadelphia Convention. Indeed, James Madison delayed publication of his notes from Philadelphia until after his death in 1836 in part because of his desire that the Convention records be subordinated to the public legislative history of constitutional ratification:

Mr. [Madison] said, he did not believe a single instance could be cited in which the sense of the Convention had been required or admitted as material in any Constitutional question. ...

But, after all, whatever veneration might be entertained for the body of men who formed our Constitution, the sense of that body could never be regarded as the oracular guide in expounding the Constitution. As the instrument came from them, it was nothing more than the draft of a plan, nothing but a dead letter, until life and validity were breathed into it by the voice of the people, speaking through the several State Conventions. ${ }^{33}$

This way of thinking about constitutional history confirms the primacy of The Federalist: Not only is it the most comprehensive, rich, and cogent work of those who supported the Constitution, it was expressly written to explain and defend that document to the People during the ratification period-and was widely used for that very purpose. On the other hand, primary reliance on Madison's notes becomes more problematic. At best, the notes should be seen as accurate but indirect evidence of the way many leaders in 1787 thought, and of the things that many are likely to have said during the ratification process in speeches and conversations of which no reliable transcript exists today.

In theory, records of the state ratifying conventions are better evidence than records from Philadelphia, because ratification debates by definition $^{34}$ constitute popular and public history-history of, by, and for the

republished 1971).

32. See, e.g., J. Elliot, The Debates of the Several State Conventions on the AdopTION OF THE FEDERAL CoNSTITUTION (1888).

33. 5 Annals of Cong. 776 (1796) (remarks of Rep. James Madison); see also 3 FarRand RECORDS, supra note 4, at 447-48 (Sept. 15, 1821 letter from James Madison to Thomas Ritchie); R. Ketcham, James Madison: A Biography 661-62 (1971). See generally Powell, The Original Understanding of Original Intent, 98 HaRv. L. REv. 885, 921, 938-39 (1985).

34. The word "convention" is an 18th century term of art denoting an assembly that is the virtual embodiment of the People. See Amar, supra note 28, at 1459-60; see also G. Wood, ThE Creatron OF THE AMERICAN REPUBLIC 1776-1787, at 306-89 (1969); Ackerman, The Storrs Lectures: Discov- 
People. However, recent historical research has cast doubt on the accuracy of the various transcripts of ratification debates, and so other primary sources, more indirect but more accurate, may be preferable. ${ }^{35}$ One obvious possibility often overlooked today is the rich assortment of pamphlets-pro and con-generated during the ratification struggle. Of course, we must exercise special caution in using writings of those who opposed the Constitution and lost; their understandings of the meaning of the document may often be inferior to the Federalists'. But in many cases, Anti-Federalist literature may help 20th century lawyers confirm Federalist readings. For example, leading pamphleteers from the two camps often agreed about what a particular clause (such as the preamble) ${ }^{36}$ meant, or whether a given doctrine (such as judicial review) ${ }^{37}$ was implicit in the plan; they disagreed only about whether such provisions commended or condemned the document.

The tendency of 20th century lawyers to undervalue less accessible historical materials is perhaps most dramatic and unfortunate in our treatment-or more precisely, our lack of treatment-of the historical materials surrounding the Reconstruction Amendments. There are no primary sources from this era analogous to The Federalist or even Farrand: The Congressional records are scattered and hard to come by, and the sources of popular legislative history during ratification are even more difficult to locate and work with. All this leads me to wonder whether our undervaluation of the Reconstruction primary sources has contributed to an undervaluation of the Reconstruction Amendments themselves. We end up thinking less about the Reconstruction than about the Founding, and may therefore miss some of the beauty, some of the tragedy, and some of the promise embedded in the Civil War Amendments. We are more likely to mistakenly view the Amendments as an afterthought-a footnote-rather than a glorious and agonizing rebirth of the nation. ${ }^{38}$

\section{Heroic History}

If one moral of my story is that bad history can make bad law, another, more ironic, lesson is that good history can sometimes do the same. History is largely storytelling, and good storytelling often calls for a hero. ${ }^{39}$

ering the Constitution, 93 YAL.E. L.J. 1013, 1058-70 (1984).

35. See Hutson, The Creation of the Constitution: The Integrity of the Documentary Record, 65 Tex. L. Rev. 1 (1986).

36. See Amar, supra note 28 , at $1450,1455-56,1461$ n.157.

37. See G. Wills, Explaining America 130-35 (1981).

38. Nowhere is the devaluation of Reconstruction more evident than in college and law school curricula in constitutional law courses. Our future leaders and lawyers spend far less time studying primary sources from the Reconstruction than from the Founding. Cf. Powell, supra note 33, at 945 (tracing increased "popular and legal interest" in original intent of framers and ratifiers to "growing availability of original materials" during mid-nineteenth century).

39. See W. Cronon, Stories Without Heroes: Narrating Environmental Change (1987) (unpublished manuscript on file with author). 
But it is easier to spin an epic yarn about a handful of demigods in Philadelphia than about the thousands of relatively anonymous and more ordinary citizens who made the Constitution law by ratifying it. Madison's notes possess a Shakespearean drama, a Thucydidean pungence, that few other primary sources can rival. Thus, it is not surprising that in telling and re-telling each other the story of the 1780's, 19th and 20th century Americans have focused on the "framers" at Philadelphia rather than the "ratifiers" everywhere-a focus reflected and reinforced by the fascination with the four page original that bears Their holographic signatures.

I do not mean to denigrate the importance of, or the need for, heroic history. Part of the purpose of history, I believe, is to provide us today with models of virtue in action whom we should aspire to emulate. ${ }^{40}$ The founding fathers shared this understanding of history. To take but two examples, George Washington self-consciously patterned himself after the Roman hero Cincinnatus, and the authors of The Federalist adopted the pen name "Publius," another classical hero celebrated by the Roman historian Plutarch. ${ }^{41}$ The framers' understanding of heroic history was not simply backward-looking. At the same time they looked to past heroes for instruction and edification, they themselves sought to become heroes who could inspire future generations.

They succeeded too well. The very grandeur of Washington, Madison, and Hamilton distances them from us. They loom so large that we today despair of ever equalling their greatness. And so instead of spurring us to great deeds, the heroism of the demigods lulls us into a complacent acceptance of our own mediocrity. The Constitution becomes a closed book, rather than an ever unfolding saga. The parchment becomes a literally untouchable relic of a bygone age when giants walked the earth.

Our identification of the Constitution with a handful of mythic heroes also leads us to sanitize history. Because we have personalized the document, to dwell on its defects-the intricate network of clauses protecting human slavery is of course the most dramatic example-is almost to levy a personal attack on its "father," James Madison. And so we avert our eyes from some clauses, we hesitate to say some things, lest we besmirch our heroes and blaspheme our demigods.

\section{Hermetically Sealed History}

Most good stories have endings, and it has been tempting for Americans to end the story of our Constitution prematurely in the 1780's. Thus, heroic history can all too easily decay into what I shall call hermetically

40. I think Bob Cover shared this view of history. See Tributes to Robert M. Cover, 96 YALE L.J. 1699, 1715-16 (1987) (tribute by Tanina Rostain).

41. See generally G. Wills, supra note 37; D. AdAIR, FAmE and the Founding Fathers (1974); G. Wills, Cincinnatus: George Washington and the Enlightenment (1984). 
sealed history. The current display of the parchment at the National Archives is illustrative: Awestruck, we gaze at a closed, self-contained, 18th century collection of yellowed papers whose distance from us is underscored by its quaint capitalization of every noun, its proud display of signatures of great men long dead, and its very handwrittenness. Symbolically, at least, the September 28 print seems preferable. Precisely because it is "only" a print, it is more open, more continuous with subsequent amendments, less forbidding and untouchable, more usable and popular. ${ }^{42}$ (Indeed, it is also quite human: For example, Article III of the print contains an obvious printer's error in its reference to "inferior court" instead of "inferior courts.") 43

Perhaps I am reading too much into the iconography of public exhibition. After all, how we display the Constitution is far less important than how we interpret it. But the way we exhibit the document simultaneously mirrors and shapes the way we think about it, and, thus, the way we give it legal meaning. And here, whatever its source, the danger of hermetically sealed history is very real.

Richard Epstein's recent book, Takings, offers a nice illustration. ${ }^{44}$ Professor Epstein's basic argument is that redistributive legislation offends the deep structure of the federal Constitution. If we look only at the 18th century Constitution, hermetically sealed, Epstein's interpretation is quite plausible, though not beyond doubt; without too much eyestrain, the takings, contracts, bill of attainder, bills of credit and ex post facto clauses can all be seen as embodiments of a general anti-redistributive constitutional ethos. However, once we widen our focus to the entire Constitution, as amended, it is hard to reach Epstein's result without serious squinting. In 1913, We the People of the United States ratified the Sixteenth Amendment to our Constitution expressly authorizing a federal income tax. The popular legislative history of ratification reveals not merely an endorsement of an income tax simpliciter, but popular approval of a predictably progressive-that is, a redistributive-income tax. However

42. In contrast to a handwritten parchment that can be in only one place at a time, a printed constitution enjoys dramatic democratic possibilities, which were nicely captured by Thomas Paine's discussion of the Pennsylvania Constitution of 1776:

It was the political bible of the state. Scarcely a family was without it. Every member of the government had a copy; and nothing was more common, when any debate arose on the principle of a bill, or on the extent of any species of authority, than for the members to take the printed constitution out of their pocket, and read the chapter with which [such] matter in debate was connected.

T. Paine, Rights of Man, Part II, 28 (4th American ed. 1794), reprinted in The Life and Major Writings of Thomas Paine 345, 378 (P. Foner ed. 1945).

43. See infra Appendix I. Given that the omission of the letter " $\mathrm{s}$ " is an obvious printer's error-as confirmed by the preceding sentence of Article III and by Article I, § 8, cl. 9, both of which refer to "inferior courts"-nothing should turn on this mistake, except a realization that the framers were not perfect. For that very reason, the path to constitutional amendment was left open. See infra text accompanying note 50 .

44. R. Epstein, Takings (1985). 
broadly one reads the provisions of the 18th century Constitution, are not subsequent constitutional amendments entitled to at least as broad a reading? ${ }^{45}$

To see the point more sharply, consider the following question: May a woman serve as President of the United States? If we focus solely on the 18th century Constitution, hermetically sealed, a plausible (though by no means decisive) argument can be made for ineligibility. Over and over, Article II uses the words "he" and "his" to refer to the President. (Articles I and III, incidentally, have no analogous language concerning Representatives, Senators, and Judges.) Of course, it is quite possible that the masculine pronouns in Article II were intended to apply generically to both sexes. However, contemporaneous usage tends to weaken this hypothesis. For example, an early draft of the fugitive slave clause used the phrase "He or She," suggesting that the masculine pronoun was generally understood as gender-specific. ${ }^{46}$ Nor can we assume that the men who wrote and ratified the Constitution used "he" unthinkingly, never imagining that a woman could serve as a head of state. Virginia, after all, took its name from one such woman (Elizabeth) and its oldest school (William and Mary) bore the name of another. Yet never, to my knowledge, was the President likened to a Queen during the ratification era-although references to Kings were commonplace.

But however broadly we read the text and history of Article II, is not the promise of the Nineteenth Amendment entitled to at least as broad a reading? Admittedly, that Amendment does not explicitly modify Article II-but Article II of course does not explicitly require that the President be male, in sharp contrast to its clear mandate that the President, for example, be at least 35 years of age. ${ }^{47}$ Once we widen our focus-as we

45. It is revealing that in a 350 page book, Professor Epstein devotes exactly one footnote to the Sixteenth Amendment. Despite his willingness early on to read the Constitution as "draw[ing] on the basic theory developed by Locke," id. at 31, Epstein shows a curious unwillingness to look in similar fashion beyond constitutional text to historical context when discussing the 1913 Amendment. Instead, Epstein blandly asserts-without any historical analysis-that the Amendment "does not address fairness between individuals." Id. at 296 n. 42.

Although this essay is not the place to attempt to adduce detailed evidence casting doubt on Epstein's claim, surely the issue deserves more attention than his book accords it.

46. 2 FARRAND Records, supra note 4, at 577 (Committee of Style Draft).

One should not place great weight on this rather slender datum. For one thing, the rejection of the draft language may have been based, at least in part, on stylistic concerns about the redundancy of the words "or She." More important, even if it could be convincingly demonstrated that the delegates at Philadelphia used the words "he" and "his" to refer only to men, it would remain to be shown that the People shared this understanding during ratification. In the event of any divergence between a secret language created by the Philadelphia delegates and the popular understanding of the Constitution's words during the ratification era, the latter must of course guide legal interpretation.

47. In phrasing my argument in this way, I seek to sidestep the "level of generality" question that confronts anyone who attempts to faithfully interpret constitutional text. See J. ELY, DEMOCRACY AND DisTRUST 61 (1980). Thus, I do not argue that after the adoption of the Twenty-sixth Amendment, the President need be only 18 years old. Since Article II is far more explicit than the Amendment on the issue of age and Presidential eligibility, any argument that the later text repealed the earlier one sub silentio would require an interpretive rule that read newer texts far more generously than older ones. 
must-beyond our hermetically sealed parchment, we must give due respect to the vision of political equality informing the Nineteenth Amendment-a vision that has implications not just for presidential eligibility, but also, I believe, for gender equality in jury selection, ${ }^{48}$ and perhaps for other areas as well. ${ }^{49}$

\section{a. Our Conservative Constitution}

There is a more general point here. Because the Constitution was written and ratified in the past, in one sense it is almost by definition a "conservative" document. This is perhaps one of the reasons that political conservatives today are more likely than liberals to pledge allegiance to "original intent." But conservatives sometimes cheat: They exaggerate the natural conservatism of the document by paying undue attention to the 18 th century parchment and by slighting more recent amendments. The world view of a Richard Epstein or a William Rehnquist may well be closer to the Federalists' of the 1780's than to the Republicans' of the 1860 's or the Progressives' of the 1910's, but any attempt to faithfully discern and apply the Constitution must take more modern expressions of popular sovereignty at least as seriously as more ancient ones. Mine is not an invitation to noninterpretivism based on a vague theory of changed circumstances, but a reminder to interpretivists to respect the sovereign right of post-eighteenth century Americans to alter their form of government by constitutional amendment.

\section{b. Our Radical Constitution}

If the Constitution is in one sense conservative, in two other obvious senses it is quite radical. First, its foundational principle-popular sovereignty-empowers the People even as it limits their government servants. Because of popular sovereignty, We the People of 1987 need not be bound by words penned in 1787 , but may alter those words at will by constitutional amendment. No constitutional provision is a straightjacket any longer than We wish it to be. Indeed, I have argued elsewhere that popular sovereignty, properly understood, implies that the People today may amend their Constitution in ways that transcend the formal rules of Article V. ${ }^{50}$ To believe otherwise is to kill the principle that gives the Constitution life, and allow the hand of a People long dead to thwart the sovereign right of the American People today to govern themselves.

Second, any theory of constitutional interpretation that takes the docu-

48. See Note, Choosing Representatives by Lottery Voting, 93 YALE L.J. 1283 (1984) (discussing parallels between voting and serving on juries).

49. Cf. Calabresi, Bakke As Pseudo-Tragedy, 28 CATH. U.L. Rev. 427, 441 n.33 (1979) (exploring Nineteenth Amendment's implications for affirmative action for women).

50. See Amar, supra note 28, at 1464-65; accord Ackerman, supra note 34, at 1056-70. 
ment seriously coexists uneasily with the principles of gradualism and respect for precedent. Suppose, for example, that on the basis of newly discovered historical evidence, an interpretivist judge is convinced that earlier cases, around which expectations have now crystallized, have misinterpreted the meaning of the People's supreme law. By what right does that judge follow precedent and thus judicially amend the Constitution? ${ }^{51}$ The question has been highlighted by the recent confirmation hearings of Robert Bork, who apparently believes that many 20th century Supreme Court cases are incorrect because they deviate from the text, history, and structure of the Constitution.

Indeed, the existence of the September 28 print provides an apt hypothetical: What if, on the basis of this print, an interpretivist judge believes earlier case law of a given clause (based on the differently punctuated parchment) is in error? Fortunately, I do not believe any sophisticated interpretivist need ever reach this question. The differences between print and parchment seem to me far too minor to affect the document's meaning. Properly understood, interpretivism is not a cryptographic hunt for the Constitution's secret meaning, but a modest and commonsensical enterprise that does not seek more determinacy than the sources fairly yield. To be sure, a careful examination of constitutional text, history and structure will often leave us with a clear answer. ${ }^{52}$ At other times, however, the most the document can yield is the right set of questions to ask ourselves. ${ }^{\text {ss }}$ No group of words-old or new, conservative or radical-can do more.

\section{ConClusion}

Ironically, the very boldness of script with which the National Archives parchment proclaims its first three words invites us to reconsider the document's authoritative status as the official copy of the Constitution. If taken seriously, those three words-and the theory of popular sovereignty be-

51. Perhaps this rhetorical question could be neutralized by two counterquestions, also rooted in interpretivism: By what right do judges treat case law interpreting the Constitution with less respect than case law interpreting statutes? If the Article III phrase "judicial power" permits (or requires) respect for precedent when dealing with statutes or treaties, why doesn't that same phrase permit (or require) respect for precedent when dealing with the Constitution?

The standard answer to these questions-that precedent must be accorded less weight in constitutional law because "correction" of an erroneous constitutional case "through legislative action is practically impossible," Burnet v. Coronado Oil \& Gas Co., 285 U.S. 393, 406-07 (1932) (Brandeis, J., dissenting)-is forceful but perhaps a bit too quick. Cf. Amar, supra note 25, at $258 \mathrm{n} .170$ (discussing jurisdiction-stripping statute, passed by ordinary legislative process, as possible means of circumventing extant judicial precedent).

Thus, the relationship between interpretivism and precedent is more complicated than my initial rhetorical question in the text may indicate.

52. See, e.g., Amar, supra note 28, at 1473-84 (suggesting clear answers to questions surrounding meaning of Eleventh Amendment); Amar, supra note 25 (suggesting clear answer to question regarding congressional power to strip jurisdiction from federal courts).

53. Cf. Amar, supra note 25, at 258 n.169 (noting that language of Fourteenth Amendment is far less precise than language of Article III). 
hind them-point us towards another document: the September 28 print. Most important, those three words invite us to reconsider how we use history to interpret our supreme law, and how we can make history by changing it. 
Appendix I: A Comparative Sample of Print and Parchment

\author{
September 28 Print $^{54}$
}

ARTICLE III.

Sect. I. The judicial power of the United States, shall be vested in one supreme court, and in such inferior courts as the Congress may from time to time ordain and establish. The judges, both of the supreme and inferior court, shall hold their offices during good behaviour, and shall, at stated times, receive for their services, a compensation, which shall not be diminished during their continuance in office.

Sect. 2. The judicial power shall extend to all cases, in law and equity, arising under this constitution, the laws of the United States, and treaties made, or which shall be made, under their authority; to all cases affecting ambassadors, other public ministers and consuls; to all cases of admiralty and maritime jurisdiction; to controverises to which the United States shall be a party; to controversies between two or more states, between a state and citizens of another state, between citizens of different states, between citizens of the same state claiming lands under grants of different states, and between a state, or the citizens thereof, and foreign States, citizens or subjects.

In all cases affecting ambassadors, other public ministers and consuls, and those in which a state shall be party, the supreme court shall have original jurisdiction. In all the other cases before mentioned, the supreme court shall have appellate jurisdiction, both as to law and fact, with such exceptions, and under such regulations as the Congress shall make.

54. The complete text of this edition can be found at S. Doc. No. 49, supra note 1, at 1-23. 


\section{September 17 Parchment ${ }^{\text {s5 }}$}

Article III.

Section. 1. The judicial Power of the United States, shall be vested in one supreme Court, and in such inferior Courts as the Congress may from time to time ordain and establish. The Judges, both of the supreme and inferior Courts, shall hold their Offices during good Behaviour, and shall, at stated Times, receive for their Services, a Compensation, which shall not be diminished during their Continuance in Office.

Section. 2. The judicial Power shall extend to all Gases, in Law and Equity, arising under this Constitution, the Laws of the United States, and Treaties made, or which shall be made, under their Authority;Cases affecting Ambassadors, other public ministers and Consuls; - to all Cases of admiralty and maritime Jurisdiction; - to Controversies to which the United States shall be a Party;-to Controversies between two or more States;-between a State and Citizens of another State;-between Citizens of different States;--between Citizens of the same State claiming Lands under Grants of different States, and between a State, or the Citizens thereof, and foreign States, Citizens or Subjects.

In all Cases affecting Ambassadors, other public Ministers and Consuls, and those in which a State shall be Party, the supreme Court shall have original Jurisdiction. In all the other Cases before mentioned, the supreme Court shall have appellate Jurisdiction, both as to Law and Fact, with such Exceptions, and under such Regulations as the Congress shall make.

55. The complete text of this edition can be found at S. Doc. No. $82,92 d$ Cong., $2 d$ Sess. 1-21 (1973). 
Appendix II: A Summary of Major Constitutional Drafts

Document Comments

\begin{tabular}{|l|l|}
\hline September 12 print & $\begin{array}{l}\text { Draft prepared by Philadelphia Committee } \\
\text { of Style; working paper of Convention del- } \\
\text { egates during final days at Philadelphia. }\end{array}$ \\
\hline September 17 parchment & $\begin{array}{l}\text { Authorized on September 15 by Philadel- } \\
\text { phia Convention; signed by 39 delegates } \\
\text { two days later; sent to Congress in New } \\
\text { York; apparently lost until 1818; on dis- } \\
\text { play at National Archives. }\end{array}$ \\
\hline September 18 print & $\begin{array}{l}\text { Authorized simultaneously with parch- } \\
\text { ment; differed from parchment in punctua- } \\
\text { tion, etc.; probably provided basis for } \\
\text { working paper of members of Congress; } \\
\text { provided basis for September 28 print. }\end{array}$ \\
\hline September 28 print & $\begin{array}{l}\text { Authorized by Congress; based on Septem- } \\
\text { ber 18 print; reprinted in states for use by } \\
\text { the People during ratification; expressly in- } \\
\text { cluded in nine state ratification instru- } \\
\text { ments; reprinted as "correct" copy of Con- } \\
\text { stitution in 1789 under direction of new } \\
\text { government. }\end{array}$ \\
\hline
\end{tabular}

